\title{
Skal det jobbe mennesker i norske sykehus?
}

Sykehus er primært til for pasientenes skyld. Men de er også arbeidsplass for tusenvis av mennesker. Disse er ikke roboter, men mennesker med behov for å trives på arbeidsplassen og føle seg verdsatt. Også dette er viktig hvis et nytt sykehus skal bli en suksess.

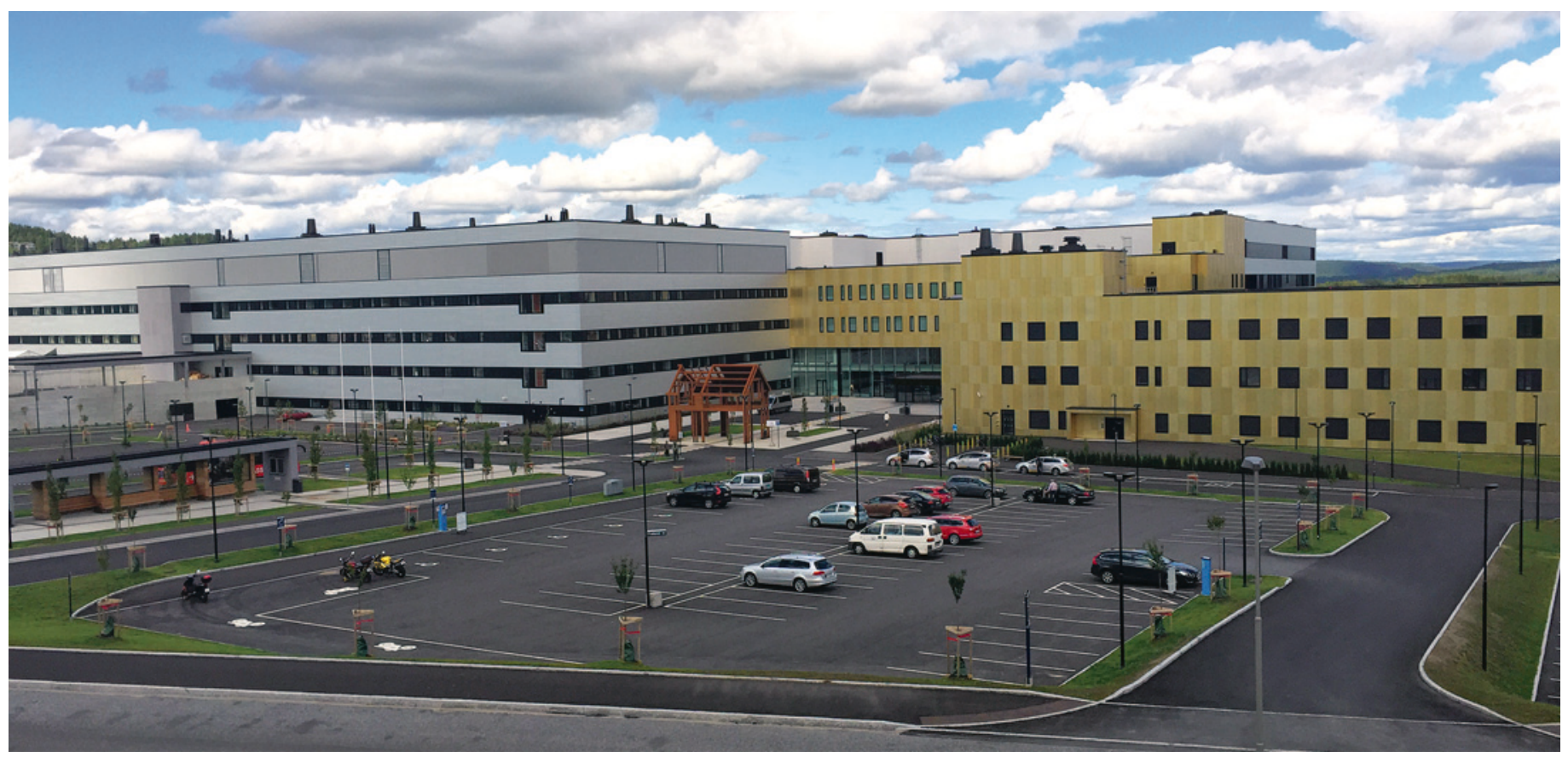

Figur 1 Et helt nytt norsk sykehus for somatikk (til venstre) og for psykiatri (til høyre). Foto: Tidsskriftet, bildet er redigert

Forleden besøkte jeg et nytt norsk sykehus. Det har vært i drift i mindre enn ett år. Hvor mange milliarder det har kostet, der det ligger i ingenmannsland mellom to byer, vet jeg ikke, men det er nok mange. Sykehuset kan i praksis bare nås med bil. I en tid da mange er opptatt av miljøet, er det et alvorlig problem. Det er et stort parkeringsareal utenfor, som overvåkes av et privat og etter sigende meget aktivt parkeringsfirma. Det er fort gjort å få bot hvis man blir forsinket i sitt ærend i sykehuset.

Ved ankomsten ser man to bygninger (fig 1). Den ene (somatikkdelen) er hangaraktig med horisontale fasadeplater i noe som ser ut som matt aluminium, det andre (psykiatridelen) har gulspraglete vertikale fasadeplater og noen underlige, flate tårn. Det er fullkomment stilbrudd mellom de to sammenvokste bygningene. Helhetsinntrykket er utsøkt stygt. Signalet er at somatikk og psykiatri er to verdener som er tvunget innpå hverandre, men som ikke har noe med hverandre å gjøre. Man har vel fått arkitektbistand på anbud der pris har vært eneste kriterium.

Vel inne veiledes man av et $-i$ hvert fall for oss ikke helt unge - ubegripelig fargesystem. Heldigvis finnes det en informasjonsdisk hvor man kan få hjelp. Etter hvert kom jeg frem til laboratoriemedisinsk senter, som var mitt mål. Der ble jeg dypt imponert av hvor mye som er investert i maskineri og teknisk utstyr og av graden av funksjonalitet og automatisering. Men det gjorde enda større inntrykk at det, også i de knepne vaktrommene, var forbudt å henge annet enn

\section{«Helsetjenesten er}

mer enn pakkeforløp,

mer enn industri»

«driftskritiske» ting på veggene. Det fantes ikke et bilde, ikke en kalender, knapt nok en hylle til permer eller bøker. Jeg har knapt sett en arbeidsplass som ga et mer sterilt inntrykk, ikke bare i rentrom og sterilsoner, men overalt.

\section{Sykehus er til for pasientene - men også for medarbeiderne}

Mitt spørsmål blir derfor: Har man glemt at det skal jobbe mennesker her? Har man glemt at mennesker skal tilbringe en tredel av døgnet på dette stedet - skal trives, bevare entusiasmen for faget sitt og bidra til å utvikle det videre? Er man blitt så begeistret for industritenkning, pakkeforløp, maskiner, roboter og automatikk at man har glemt at i helsevesenet er det mennesker som jobber for mennesker?
Jeg ble rystet av sykehusets plassering, av dets ytre arkitektur og av forbudet mot selv det minste forsøk på å gjøre arbeidsplassen litt personlig. Hvis en slik robotkultur får slå rot, vil de fleste medarbeiderne nøye seg med å komme på jobb, gjøre den for å få sin lønn og dra hjem igjen. Sykehusene er til primært for pasientene, men de er også arbeidsplassen til tusenvis av mennesker. Blir det glemt, vil kvaliteten på ytelsene uvegerlig bli redusert. Helsetjenesten er mer enn pakkeforløp, mer enn industri.

\section{Hans Erik Heier}

heheier@online.no

Hans Erik Heier (f. 1944) er professor emeritus i transfusjonsmedisin ved Universitetet i Oslo og tidligere avdelingsoverlege ved Avdeling for immunologi og transfusjonsmedisin, Oslo universitetssykehus. Han har en mastergrad i helseledelse fra Universitetet i Oslo. Forfatter har fylt ut ICMJE-skjemaet og oppgir ingen interessekonflikter.

Mottatt 11.5. 2016 og godkjent 19.5. 2016. Redaktør: Ketil Slagstad.

Publisert først på nett. 